\title{
The Role of Credit in the Exit of Firms Across U.S. Industries During the Great Recession
}

Matthew Famiglietti, Research Associate

Fernando Leibovici, Economist

W

hile much has been written about the importance of financial markets in the collapse of the U.S. economy during the Great Recession (for example, see Gertler and Gilchrist, 2018, for a review of the academic literature on this topic), there is no consensus about how to properly measure the role of this channel in the data.

During the Great Recession, firms in industries with higher shares of delinquent firms were more likely to go out of business.

This essay exploits a novel dataset with information on the credit ratings of all firms in the U.S. economy to study how financial factors might account for the extent to which firms have gone out of business during the Great Recession. To identify the role of financial factors, we examine the correlation between delinquencies and exit rates across U.S. industries.

We use the Dun \& Bradstreet (D\&B) National Establishment Time Series (NETS) database, which provides detailed data on all U.S firms, including 3-digit North American Industry Classification System codes and D\&B's commercial credit ratings, termed PAYDEX ${ }^{\circledR}$ scores. PAYDEX scores reflect the timeliness of firms' credit payments. Credit payment delinquency of greater than 90 days implies severe credit problems for firms. We compare industry-level delinquency rates with industry-level exit rates between 2007 and 2011; for a given industry, we measure the latter as the proportion of firms that existed in 2007 but ceased to exist by $2011 .^{1}$

The table lists the 10 industries with the highest and lowest delinquency rates, respectively, over the Great Recession. On the low end, of the firms in these industries, which are primarily engaged in manufacturing and natural resource extraction, only 0.27 percent were severely delinquent, while 19.74 percent exited between 2007 and 2011. On the high end, of the firms in these industries, which
Delinquency and Exit Rates Across Industries, 2007-11

Delinquency rate

Industry $\quad(90+$ days, \%) $\quad$ Exit rate $(\%)$

Industries with lowest delinquency rates

$\begin{array}{lll}\text { Utilities } & 0.09 & 19.44\end{array}$

$\begin{array}{lll}\text { Forestry and Logging } & 0.12 & 16.57\end{array}$

Oil and Gas Extraction $\quad 0.18 \quad 24.77$

$\begin{array}{lll}\text { Paper Manufacturing } & 0.24 & 24.80\end{array}$

$\begin{array}{lll}\text { Petroleum and Coal } & 0.26 & 21.79\end{array}$

Manufacturing

$0.34 \quad 21.14$

Product Manufacturing

Mining

$0.34 \quad 21.84$

Funds, Trusts, and Other

Financial Vehicles

0.38

29.30

Human Resources Admin.

Other Information Services

0.39

9.03

Average

0.27

8.66

Industries with highest delinquency rates

\begin{tabular}{lcc}
$\begin{array}{l}\text { Personal and Laundry } \\
\text { Services }\end{array}$ & 1.94 & 22.30 \\
\hline $\begin{array}{l}\text { Truck Transportation } \\
\text { Administrative and Support } \\
\text { Services }\end{array}$ & 1.96 & 21.95 \\
\hline $\begin{array}{l}\text { Credit Intermediation and } \\
\text { Related Activities }\end{array}$ & 2.11 & 25.19 \\
\hline Data Processing and Hosting & 2.19 & 34.95 \\
\hline Construction of Buildings & 2.24 & 30.87 \\
\hline $\begin{array}{l}\text { Telecommunications } \\
\text { Scenic and Sightseeing }\end{array}$ & 2.42 & 22.37 \\
\hline $\begin{array}{l}\text { Transportation } \\
\text { Transit and Ground }\end{array}$ & 2.86 & 38.41 \\
\hline Passenger Transportation & 2.86 & 19.05 \\
\hline Couriers and Messengers & 2.95 & 28.31 \\
\hline Average & 2.37 & 31.97 \\
\hline
\end{tabular}

SOURCE: D\&B NETS database. 


\section{Exit Rates by Industry, 2007-11}

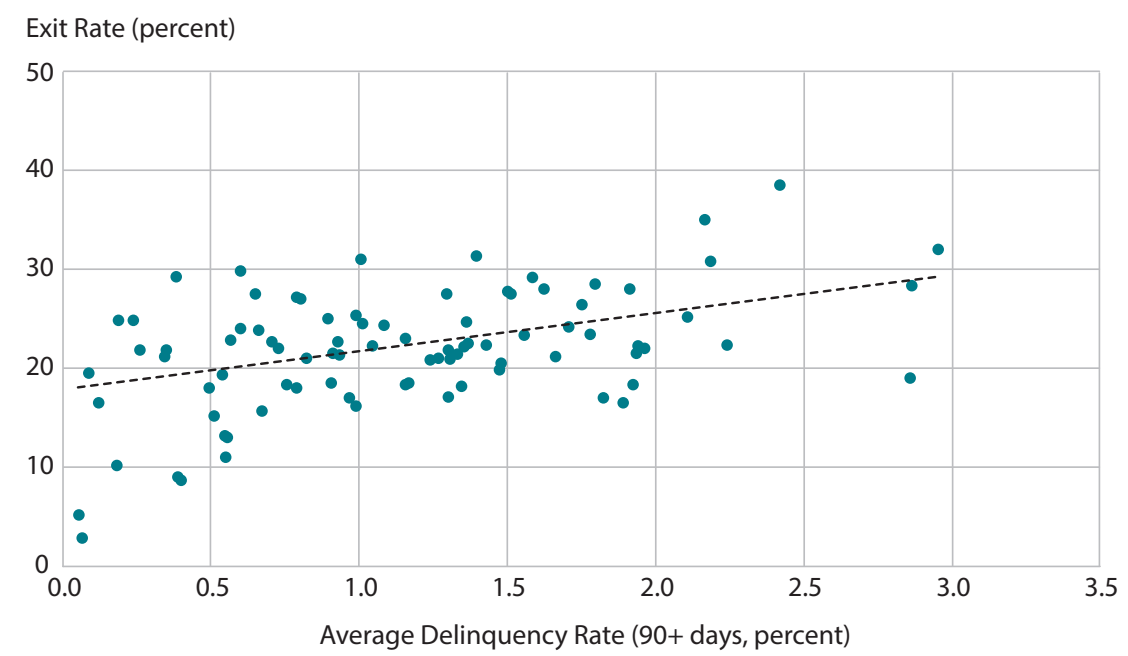

NOTE: $R^{2}=0.1316, \beta=3.8469, P=(0.0005)$.

SOURCE: D\&B NETS database and authors' calculations.

are primarily engaged in transportation, 2.37 percent were severely delinquent. The firms in these industries had much higher exit rates, with 27.54 percent exiting between 2007 and 2011.

The observations in the table show that few firms were delinquent for more than 90 days over the 2007-11 period. Even the industries with the highest levels of delinquency had rates below 3 percent. Nevertheless, this statistic provides information about the industries' financial health at the time and their potential resilience to shocks.

The scatterplot shows the relation between industrylevel delinquency rates and the exit of firms across industries over the 2007-11 period. The share of severely delinquent firms is strongly correlated with the industry's exit rate: Industries with many distressed firms experienced a higher exit rate. That is, while there is wide dispersion in industry-level exit rates, we find that industry-level variation in financially related variables explains a significant share of it. The coefficient of the best-fit line through the data is 3.85, implying that a 1-percentage-point increase in the delinquency rate is associated with a 3.85-percentagepoint average increase in the exit rate. That is, firms in industries with higher shares of delinquent firms were more likely to go out of business.

Firms might have exited during the crisis either because of the long-term unsustainability of their operations (insolvency) or because of limited short-term access to financial markets (illiquidity). Insofar as we observe a positive relationship between delinquency and firm-exit rates, we interpret it as evidence that financial factors-that is, illiquidity - might have played a significant role in accounting for the degree to which firms went out of business across U.S. industries during and shortly after the Great Recession. More generally, delinquency rates point to the potentially important role that financial markets play in the health and survival of firms. Nevertheless, more research needs to be conducted to identify whether insolvency or illiquidity drove the exit of firms during the crisis and to evaluate the extent to which the correlation observed in the figure is causal or whether some third factor drives both exit and delinquency rates. Ultimately, we would like to understand whether and how policy might assist firms to survive financial crises.

\section{Note}

1 We study a 5 percent random sample of establishments associated with
firms that average more than five employees throughout the duration of the
firm. An "establishment" is one location of a firm, such as a retail outlet or an
office. While the database is organized at the establishment level, we examine
firms as a whole by aggregating employees over all establishments of a firm.

\section{Reference}

Gertler, M. and Gilchrist, S. "What Happened: Financial Factors in the Great Recession." Journal of Economic Perspectives, 2018, 32(3), pp. 3-30. 